\title{
A Case of Drug-induced Hepatotoxicity: Amiodarone is Not Always to Blame
}

\author{
Brendan O'Hare, MD
}

\section{Case Presentation}

A 54 year-old male presented to the hospital with a two week history of new onset jaundice, anorexia and fatigue. The patient has a past medical history of hypertension, coronary artery disease, and ischemic cardiomyopathy with an ejection fraction of $10 \%$ to $15 \%$. He also has a history of atrial fibrillation and paroxysmal ventricular tachycardia with an automated implantable cardioverter-defibrillator placed. He denied any history of blood transfusions, alcohol use, intravenous drug abuse, or known hepatitis. He also denied taking herbal medications or vitamins. The patient denied fevers, night sweats, nausea, shortness of breath, abdominal pain, blood in his stool, or easy bruising. Four weeks prior to admission, the patient was diagnosed with hyperthyroidism thought to be secondary to long-term amiodarone use which the patient had been taking for eight years for treatment of atrial fibrillation. At that time he was started on $10 \mathrm{mg}$ of methimazole daily, and his amiodarone was stopped. All of his other medications were chronic and include atenolol, pantoprazole, aspirin, clopidogrel, and furosemide. $\mathrm{He}$ has no known drug allergies. Upon admission his methimazole was stopped since his symptoms could be attributable to this medication.

On presentation the patient was afebrile. His pulse was regular at 112 beats/minute, and his blood pressure was $91 / 61 \mathrm{~mm}$ $\mathrm{Hg}$. He was orientated to person, place, and time. His exam was noteworthy for scleral icterus and jaundice. There was no ascites, asterixis, palmer erythema, spider angiomata or other evidence of liver disease. His abdominal exam was benign, with no tenderness to palpation, organomegaly, or lymphadenopathy.
He did have $2+$ lower extremity swelling that was thought to be chronic and secondary to his heart disease.

Laboratory results are shown in Table 1 . All other laboratory values were within the reference range. An EKG did not show any acute changes, and three consecutive troponins were negative. An abdominal ultrasound was notable for the presence of hepatosplenomegaly with the liver measuring $14.4 \mathrm{~cm}$ in sagittal length and the spleen measuring $14.4 \mathrm{~cm}$. Color doppler ultrasound showed patent portal, hepatic, and splenic veins. There was no biliary ductal dilation, cholelithiasis or sludge.

On hospital day two the patient's clinical status had not improved, and a liver biopsy was obtained to help differentiate the cause of hepatic dysfunction. The liver biopsy (Figure 1) showed severe cholestasis with mild inflammatory changes and mallory bodies on pathology. Given the time course of introduction to methimazole and the development of abnormal liver tests, the presumptive diagnosis of methimazole-induced hepatotoxicity was made. The patient experienced a relatively stable course until day six of his stay. At that time the patient became clinically unstable, went into cardiac arrest and died. It was presumed that the new onset liver failure proved to be too much of a stressor on an already weak heart.

\section{Discussion}

Methimazole and its precursor molecule carbimazole are common treatment options for hyperthyroidism but do not come without significant risk to the patient: methimazole is a known hepatotoxin. An extensive review of the literature has not identified any previous case reports of methimazoleinduced liver injury leading to death in the United States. There

\begin{tabular}{|c|c|c|c|c|c|c|c|}
\hline Chem 7 & $\begin{array}{l}\text { Sodium } 140 \\
\mathrm{mmol} / \mathrm{l}\end{array}$ & $\begin{array}{l}\text { Potassium } \\
4.1 \mathrm{mmol} / \mathrm{l}\end{array}$ & $\begin{array}{l}\text { Chloride } \\
105 \mathrm{mmol} / \mathrm{l}\end{array}$ & $\begin{array}{l}\text { Carbon Dioxide } \\
21 \mathrm{mmol} / \mathrm{l}\end{array}$ & $\begin{array}{l}\text { Urea-Nitrogen } 58 \\
\mathrm{mg} / \mathrm{dl}\end{array}$ & $\begin{array}{l}\text { Creatinine } \\
2.2 \mathrm{mg} / \mathrm{dl}\end{array}$ & $\begin{array}{l}\text { Glucose } \\
136 \mathrm{mg} / \mathrm{dl}\end{array}$ \\
\hline СBC & $\begin{array}{l}\text { White Blood } \\
\text { Cell } \\
10.2 \mathrm{~b} / \mathrm{l}\end{array}$ & $\begin{array}{l}\text { Hemoglobin } \\
14.7 \mathrm{~g} / \mathrm{dl}\end{array}$ & $\begin{array}{l}\text { Hematocrit } \\
46.0 \%\end{array}$ & Platelets $137 \mathrm{~b} / \mathrm{l}$ & & & \\
\hline LFTs & $\begin{array}{l}\text { Protein } \\
5.1 \mathrm{~g} / \mathrm{dl}\end{array}$ & $\begin{array}{l}\text { Albumin } \\
2.8 \mathrm{~g} / \mathrm{dl}\end{array}$ & $\begin{array}{l}\text { Total Bilirubin } \\
26.8 \mathrm{mg} / \mathrm{dl}\end{array}$ & $\begin{array}{l}\text { Direct Bilirubin } \\
11.4 \mathrm{mg} / \mathrm{dl}\end{array}$ & $\begin{array}{l}\text { Aspartate } \\
\text { Aminotransferase } \\
107 \text { IU/I }\end{array}$ & $\begin{array}{l}\text { Alanine } \\
\text { Aminotransferase } \\
107 \text { IU/I }\end{array}$ & $\begin{array}{l}\text { Alkaline } \\
\text { Phosphatase } \\
82 \text { IU/I }\end{array}$ \\
\hline Coags & $\begin{array}{l}\text { Protime } \\
22.8 \mathrm{~s}\end{array}$ & $\begin{array}{l}\text { Prothrombin } \\
\text { Time } 33 \mathrm{~s}\end{array}$ & INR 1.90 & & & & \\
\hline Serologies & HAV IgM (-) & HAV IgG (+) & HBV Ant (-) & HBV Core (-) & HBV Ab (-) & HCV Ab (-) & \\
\hline TFTS & $\begin{array}{l}\text { Thyroid } \\
\text { Stimulating } \\
\text { Hormone } \\
0.02\end{array}$ & $\begin{array}{l}\text { Thyroxine } \\
41.5\end{array}$ & $\begin{array}{l}\text { Triiodothyronine } \\
363\end{array}$ & & & & \\
\hline
\end{tabular}

Table 1. Laboratory values at presentation. 
was a case report of necrotizing hepatitis leading to death in Germany. ${ }^{1}$ There have been case reports associating fulminant hepatic failure and death with the antithyroid agent propylthiouracil in the United States. ${ }^{2,3}$ However, up to this point methimazole liver injury has not been associated with any deaths in the United States.

There were many diagnoses in the differential that were sequentially ruled out during this patient's admission, including chronic viral hepatitis, biliary and portal vein thrombosis, infiltrative and chronic passive congestion, and ischemic liver injury. One drug considered in addition to methimazole for causing hepatotoxicity in this patient was amiodarone. It was difficult to apply the established scoring systems for assessing causality between a drug and hepatocellular injury in this case because the patient expired before rechallenge of the potential offending agent was possible. However, considering the temporality of the treatment, it is likely that methimazole and not amiodarone was the cause of liver injury. The patient had been stable on amiodarone for eight years without any noted hepatotoxicity. In contrast, methimazole had been started four weeks prior to development of jaundice. The aforementioned scoring systems for deducing the cause of drug-induced liver injury put a much greater weight on drugs that cause injury in a window of roughly five days to three months. The patient's amiodarone use did not fall into this time interval. In fact, the median time for liver disease associated with amiodarone is 21 months after initiation. ${ }^{19}$

The liver biopsy was also not consistent with amiodarone-induced liver injury. Changes in pathology that are usually associated with amiodarone drug toxicity include Mallory's hyaline, steatosis, ballooning of hepatocytes, focal necrosis, fibrosis, and in severe cases, cirrhosis. ${ }^{6}$ Although our patient did have Mallory bodies on specimen, none of the other defining characteristics of amiodarone toxicity were present. As mentioned, the biopsy showed diffuse cholestasis with intracanalicular bile plugging (Figure 1). As of 1999 there had only been seven case reports published of jaundice and cholestatisis presenting as the major clinical and pathological manifestations of amiodarone induced hepatotoxicity. ${ }^{7}$ Conversely, the majority of methimazole liver injury cases have reported cholestasis and associated jaundice..$^{8-14}$

This case serves as an example of a serious but uncommon drug related liver injury. Generally, patients with severe liver injury, as defined by serum ALT being three times the upper limit of normal or the serum bilirubin being two times the upper limit of normal in the absence of biliary obstruction, have a mortality of at least $10 \%{ }^{15}$ In our case the patient had a bilirubin that was over 20 times normal levels. Additionally, our patient had two of the three hallmarks of acute liver failure: jaundice and impaired hepatic synthetic function. During the course of his admission he did not develop the third characteristic which is encephalopathy. If the full triad of manifestations is present in cases of drug induced hepatotoxicity, patients have roughly a $25 \%$ survival rate without liver transplant.$^{16}$ However, prognosis also depends on agent as there is a $0 \%$ mortality of erythromycin induced liver failure versus $40 \%$ mortality with use of halothane. ${ }^{19}$

It is of crucial importance to recognize drug induced liver toxicity because it is now the leading cause of acute liver failure among patients referred for liver transplantation in the United States. ${ }^{17}$ Hepatotoxicity related specifically to antithyroid agents occurs with an approximate frequency of $0.1 \%$ to $0.2 \%{ }^{18}$ It is plausible, however, that this number may be falsely low secondary to difficulty in diagnosis and underreporting.

In this case, the patient's co-morbidities allowed for close physician follow up and an apparent drug induced liver injury was caught just four weeks after the inciting agent was started. However, not all patients will be followed so vigilantly after starting potentially hepatotoxic drugs. It is important for the responsible physician to be aware of potential liver injury that drugs such as methimazole may cause in order to prevent their rare but unfortunate complications.

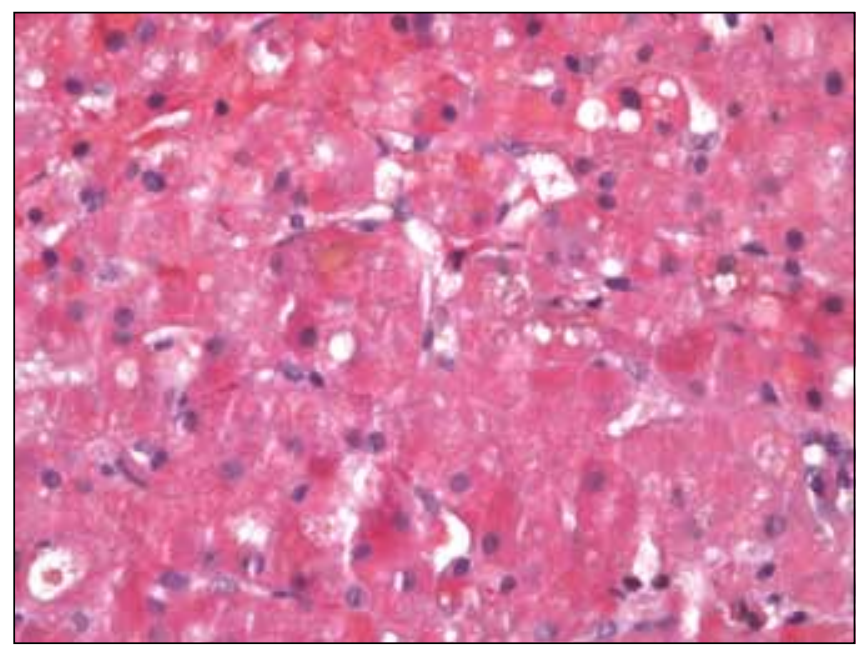

Figure 1. Liver biopsy shows diffuse cholestasis, mallory bodies, and intracanalicular bile plugging. There were no viral inclusion bodies, steatosis, necrosis, or fibrosis.

\section{References}

1. Binder C, Lang W. Necrotizing hepatitis with a fatal outcome after carbimazole therapy. Dtsch Med Wochenschr. 1993 Oct 22;118(42): 1515-9.

2. Williams KV, Natak S, Becker D, Reyes J, Burmeister LA. Fifty years of experience with propylthiouracil-associated hepatotoxicity: what have we learned? J Clin Endocrinol Metab. 1997; 82:1727-1733.

3. Ruiz JK, Rossi GV, Vallejos HA, Brenet RW, Lopez IB, Escribano AA. Fulminant hepatic failure associated with propylthiouracil. Ann Pharmacother. 2003; 37:224-228

4. Maria VAJ, Victorino RMM. Development and validation of a clinical scale for the diagnosis of drug induced hepatitis. Hepatology. 1997; 26:664-669.

5. Danan G, Benichou C. Causality assessment of adverse reactions to drugs. A novel method based on the conclusions of international consensus meetings: 
application to drug-induced liver injuries. J Clin Epidemiol. 1993; 46:1323-1330.

6. Lewis J, Mullick F, Ishak K, Ranard R, Ragsdale B, Perse R et al. Histopathologic analysis of suspected amiodarone hepatotoxicity. Hum Pathol. 1990; 21:59-67

7. Chang CC, Petrelli M, Tomashefski JF, McCullough AJ. Severe intrahepatic cholestasis caused by amiodarone toxicity after withdrawal of the drug: A case report and review of the literature. Arch of Path \& Lab Med. Mar;123(3):251-256, 1999.

8. Marazeula M, Sanchez de Paco G, Jiminez I, Carraro R, Fernandez-Herrrera J, Pajares JM, Gomez-Pan A. Acute pancreatitis, hepatic cholestasis, and erythema nodosum induced by carbimazole treatment for Graves' disease. Endocr J. 2002 Jun; 49(3): 315-8.

9. Schwab GP, Wetscher GJ, Vogl W, Redmond E. Methimazole-induced cholestatic liver injury, mimicking sclerosing cholangitis. Langenbecks Arch Chir. 1996; 381(4):225-7.

10. Hung YT, Yu WK, Chow E. Delayed cholestatic hepatitis due to methimazole. HKMJ. 1999;5:200-1.

11. Moreno Sanchez D, Medina Asensio J, Colina Ruiz-Delgado F, Campos Cantero R, Crespo Rincon L, Belda Serna A. Acute submassive cholestatic hepatitis after treatment with carbimazole. Presentation new case and review of the literature. Rev Esp Enferm Apar Dig. 1989 Sep;76(3): 273-6.
12. Cales P, Voight JJ, Suduca JM, Bord E, Vinel JP, Pascal JP. Cholestatic hepatitis caused by carbimazole. Presse Med. 1987 May 30;16(20):1005.

13. Ayensa C, Diaz de Otazu R, Cia JM. Carbimazole-induced cholestatic hepatitis. Arch Intern Med. 1986 Jul;146(7):1455

14. Blom H, Stolk J, Schreuder HB, von Blomberg-van der Flier M. A case of carbimazole-induced intrahepatic cholestasis. An immune mediated reaction. Arch Intern Med. 1985 Aug;145(8):1513-5.

15. Zimmerman HJ. Drug-induced liver disease. Clin Liver Dis. 2000(4):73-96.

16. Polson J, Lee WM. AASLD position paper: the management of acute liver failure. Hepatology 2005; 41:1179-1197.

17. Navarro VJ, Senior JR. Drug-related hepatotoxicity. NEJM. 2006(354):731-739.

18. Cooper DS. The side effects of antithyroid drugs. Endocrinologist. 1999;9:457-76.

19. Fontana RJ. Acute live failure due to drugs. Seminars in liver disease. 2008: 28; 175-187.

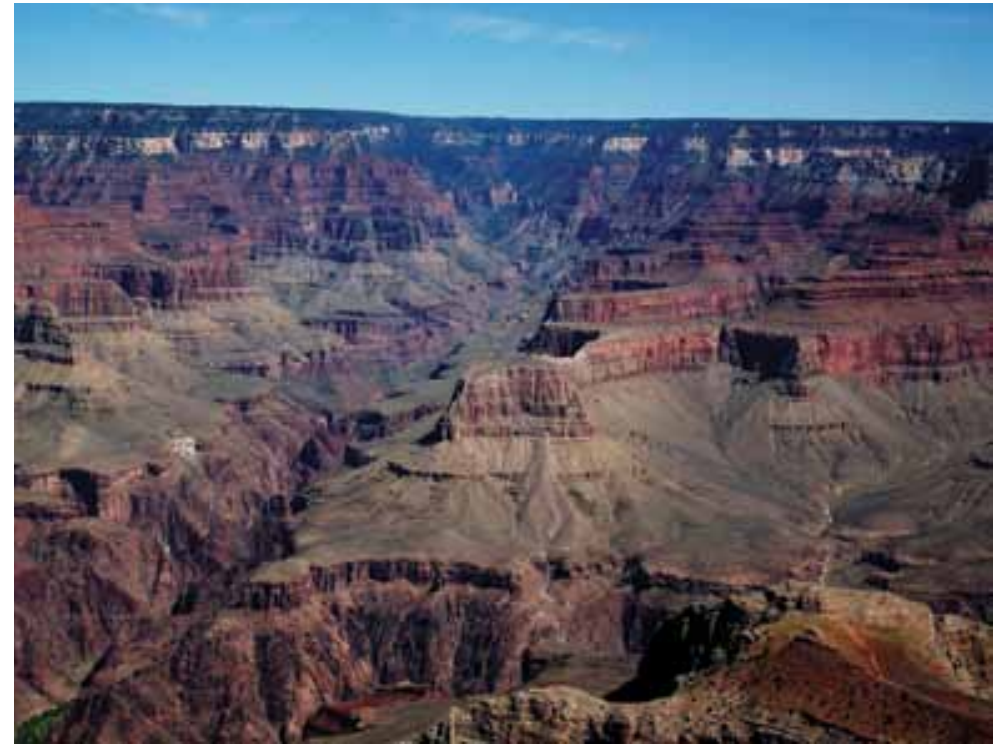

Photograph courtesy of

Esther Lee, $M D$ 